\title{
The Role of Journal Writing in Senior High School Students' Attitude toward Mathematics
}

\author{
Ivee K. Guce \\ Mathematics Department, De La Salle Lipa, Philippines
}

\begin{tabular}{|c|c|}
\hline Article Info & ABSTRACT \\
\hline Article history: & \multirow{10}{*}{$\begin{array}{l}\text { The study investigated the influence of journal writing on the senior high } \\
\text { school students' attitude toward mathematics. A mixed-method approach, } \\
\text { particularly the convergent parallel design, was used in this study. Using } \\
\text { Scale on Attitude Toward Mathematics (SATM) (Guce \& Talens, 2013), the } \\
\text { students' attitude toward the subject was measured in four subscales-liking } \\
\text { or disliking mathematics, tendency to engage in or avoid mathematical } \\
\text { activities, belief that one is good or bad in mathematics and belief that } \\
\text { mathematics is useful or useless. Using focus group discussion, the insights } \\
\text { of the students on journal writing as a mathematics class activity were } \\
\text { gathered. Results using quantitative data revealed positive significant } \\
\text { differences in the attitude of the respondents in terms of (i) liking } \\
\text { mathematics and (ii) having the tendency to engage in mathematical } \\
\text { activities. This aligned with the result in the focus group discussion which } \\
\text { suggested that students perceive journal writing as a helpful tool for them to } \\
\text { enjoy mathematics and engage in it. The activity, thus, may be regarded as a } \\
\text { means to improve students' attitude toward mathematics. }\end{array}$} \\
\hline Received May 3, 2018 & \\
\hline Revised May 21, 2018 & \\
\hline Accepted May 29, 2018 & \\
\hline Keyword: & \\
\hline Attitude & \\
\hline Journal & \\
\hline Learning & \\
\hline Reflection & \\
\hline Writing & \\
\hline
\end{tabular}

Copyright (C) 2018 Institute of Advanced Engineering and Science. All rights reserved.

\section{Corresponding Author:}

Ivee K. Guce, Ph.D.

Mathematics Department,

De La Salle Lipa,

Pres. J.P. Laurel Highway, Lipa City, Batangas, Philippines.

Email: ivee.guce@dlsl.edu.ph

\section{INTRODUCTION}

Teachers are often concerned, if not frustrated, about their students' dislike or fear of mathematics. Not only is mathematics often viewed as an irrelevant and unpopular subject [1], but lack of skill in mathematics is seldom thought of as disturbing [2]. Attempts have already been made for the purpose of improving either student engagement [3]-[4] or attitude toward the subject [5]-[9].

Literature provides evidence that the attitude of student toward mathematics plays an essential role in learning the subject. Attitude toward the subject together with academic motivation and intelligence quotient predict mathematics achievement [9]-[11]. As learners having their own personal beliefs, emotions, and views, students' attitude is part and parcel of the learning process [12]. Their motivation to learn drives them to achieve. Hence, attitude cannot be separated from learning as they are acquired through the process of learning itself [13].

Attitude toward mathematics, as defined by Ma and Kishor [14], is an "aggregated measure of liking and disliking of mathematics, a tendency to engage in or avoid mathematical activities, a belief that one is good or bad at mathematics and a belief that mathematics is useful or useless." According to Thurlow [8], attitude is even more pronounced in the area of mathematics. Attempts to improve attitude toward the subject have long been done in the past. The most widely held of which is the use of writing like math diaries, reflection, and journal writing. 
The study on the use of journals has become an important viewpoint in an effort to change the attitude of students toward mathematics. The studies of Van Der Molen [15] and Lautulippe \& Lautulippe [16] showed that inclusion of writing activities in the mathematics curriculum is beneficial to both student and teacher. Journal writing creates a supportive class atmosphere [17] and improved the classroom environment so that anxiety was less likely to interfere with learning [18]. Nahrgang and Peterson [19] were successful in using journal writing in helping students express anxieties about the subject while Miller and England [20] used the activity to determine the problems encountered by their students in the learning of mathematics. According to Ford [21], attitude toward mathematics improves as students become less anxious. Journal writing in a mathematics class has been found to reduce math anxiety resulting to an improved attitude toward the subject [17], [21]-[22].

The students' opportunity to communicate their feelings and opinions to their teacher is one important feature of journal writing. It builds a connection between the teacher and the students [23]-[26] and affords the opportunity to communicate mathematical ideas, which is one of the goals stressed in NCTM's standards [27]. Countryman [25] used journal writing as a means to have continuing dialogues with students and as a vehicle for student self-expression. Students who feel hesitant to ask questions are often willing to write what they want to tell the teacher [28]. Through the journal entries, teachers may gain important information and discover patterns of thought of their students that might otherwise be overlooked [29] not to mention that it provides the teacher with an additional means to evaluate students' understanding [17].

However, most of the studies that explored the effects of journal writing in the attitude of students toward the mathematics dealt with students from primary to junior high school [6], [8]-[9] and college [5], [30]. Not much attention has been given to studies which focus on the use of journal writing as a means to change senior high school students' attitude toward mathematics. A wide range of research concerning high school students has tended to focus on attitude as it relates to different variables like motivation, engagement, and achievement. Evidence on the role of journal writing in improving high school students' mathematics attitude remains inconclusive.

In De La Salle Lipa, students are trained to be innovative and critical thinkers being one of the Expected Lasallian Graduate Attributes. Research indicates that the use of journal improves critical thinking skills of students [31]; Dewey (1991) as cited in Lew \& Schimidt [32]. While one study involving journal writing in a college mathematics classroom [23] has already been conducted in the institution, no research using journal writing as an attempt to change the attitude of students toward mathematics appears to have been conducted thus far.

The purpose of this study was to investigate the influence of journal writing on the senior high school students' attitude toward mathematics. The following questions were addressed.

a) What is the students' attitude toward mathematics before and after journal writing was utilized?

b) Is there a significant difference in the attitude toward mathematics of the students before and after journal writing was utilized?

c) What are the students' perceptions on the influence of journal writing in their attitude toward mathematics?

This study will give awareness to teachers of the De La Salle Lipa specifically those from Senior High School Mathematics Learning Area about journal writing as a means to improve the students' attitude toward mathematics. In this paper, the argument is that through journal writing, the attitude of the students toward the subject will improve. The discussion of results is divided into two sections. The first part is on the attitudes of the students toward mathematics while the second part is on the students' insights about journal writing as a class activity.

A useful framework to understand the role of teachers' questioning as a driver to student reflection is that of Lev Vygotsky's Social Development Theory. This theory posits that "social interaction plays a fundamental role in the process of cognitive development." (Vygotsky, 1978 as cited by Youngju [33]) as he strongly believed that community plays a central role in the process of meaning-making [34]. While Piaget's notion that development precedes learning, Vygotsky argued that developmental process follows the learning process.

According to Vygotsky (1978 as cited by [34]), the learning by a child occurs though social interaction with a skillful tutor. The tutor may either model behaviors or provide instructions for the child referred to as cooperative or collaborative dialogue. The child seeks to understand the instructions given by the tutor (usually the teacher) then internalizes the information, using it to control his own performance. Vigotsky [34] mentioned that adult support allows a child to operate beyond his baseline capabilities helping him to exceed what can be attained alone.

Another framework this study is anchored on is Schön's [36] Reflection-in-Action and Reflectionon-Action. "Reflection Models and Frameworks" [37] describes reflection-in-action as something that concerns getting to the bottom of what is happening in the subject's processes, decision-making, and feelings

The Role of Journal Writing in Senior High School Students' Attitude toward Mathematics(Ivee K. Guce) 
at the time of the event of interaction. It represents a process by which one can learn from experience [38]. It is described as reflecting on the incident while it can still be beneficial to the situation as opposed to reflecting on how one would do things differently in the future [36].

Alternatively, reflection-on-action involves examining a previous event to take into account new information or perspectives that opened in relation to the subject's processes, feelings, and actions [37]. As Schön [36] put it, "we reflect on action, thinking back on what we have done in order to discover how our knowing-in-action may have contributed to an unexpected outcome" (p.26). It is basically reflecting on how practice can be improved after the event.

\section{METHOD}

Journal writing was introduced to the students as part of every meeting activity for the whole duration of the study. Its nature and purpose were likewise discussed as part of their orientation. The participants were forty-four Grade 11 senior high school students of De La Salle Lipa enrolled in one of the Precalculus classes in the first semester of school year 2017-2018. The journal writing went on for eight weeks.

Although journal writing was implemented as a permanent class activity, it was made clear to the students that it will not be part of their grade computation. The journal entries were used solely for diagnostic purposes of the teacher. The notion that journal writing is not graded initiates most of the benefits of journal writing [23]. The teacher, however, ensured that each student regularly writes in the journal by actively supervising the activity. A maximum of ten minutes was allotted for the activity, done at the end of each meeting.

Journal questions or prompts were provided by the teacher for the students to reflect on. As stated by [39], journal prompts are the most meaningful writing tasks as it involves soliciting from students' written responses to specific questions [20]. Not only does meaning-making activity enable students to develop an awareness of the self; it also allows the students to relate mathematics to real-life facts improving understanding of the subject [23].

The journal entries of the students were read and reviewed regularly and were used by the teacher to diagnose problems or concerns that the students had. It served as an open line of communication between them. Guce [23] pointed out that journaling of the students provides the teacher with another strategy for target students to communicate their thoughts. Besides, it allows the teacher to "stay in touch even with the most quiet and reserved student" [24]. Teachers in mathematics play a significant role in creating a pleasant and helpful atmosphere for their students. This leads to the improvement of the latter's feelings or beliefs toward the subject, building up to a positive attitude toward mathematics [12].

A mixed-method approach was used for this study in particular, the convergent parallel design. A mixed-method study integrates both quantitative and qualitative research methods [40]. The combined research elements are used to integrate findings within a single systematic review [41]. Creswell and Tashakkori [42] explains that the study, with its two well-developed distinct strands, each complete with its own questions, data, analysis and inferences must as well integrate, connect, or relate these strands. Heyvaert et al. [41] stressed that this method has a promising utility for research and practice as it combines the strengths of both qualitative and quantitative techniques.

For purposes of validation, convergent parallel design will be applied. According to Creswell and Plano Clark [43], this design is made to understand or develop a more concrete understanding of a research problem through analysis of different but complementary data. Two independent strands of qualitative and quantitative data will be collected and analyzed at a single phase prioritizing the methods equally. For the overall interpretation, the results will be mixed to look for convergence, divergence, contradictions, or relationships of the two sources of data. Figure 1 illustrates the process involved in this method.

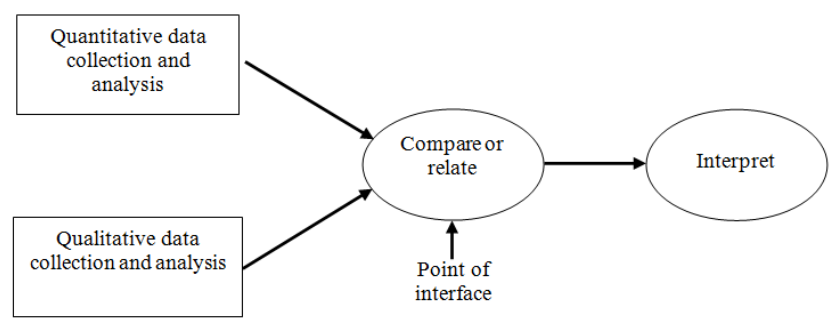

Figure 1. Convergent parallel design 
To measure the attitude of the students toward mathematics, the Scale on Attitude Toward Mathematics (SATM) by Guce \& Talens [12] was used. SATM is a 32-item scale with four subscales: liking and disliking mathematics, tendency to engage in or avoid mathematics activities, belief that one is good or bad in mathematics, and belief that mathematics is useful or useless. The instrument was administered before and after the implementation of journal writing activity.

For the quantitative data analysis, the attitude of the students toward the mathematics was described using the mean of all the responses for each of the four subscales in the pretest and posttest. To determine whethere there is a significant difference in the attitude of the students toward the subject before and after the implementing journal writing, a dependent sample t-test was done. All statistical tests were done using SPSS software.

To probe on the students' insights on journal writing, a focus group discussion was conducted. It was participated in by ten students who were randomly selected. An experienced qualitative researcher facilitated the session using the following key questions:

1. Do you like or not like mathematics?

2. Are you the type who will engage in mathematics activities or the type who will avoid them?

3. How would you describe yourself as a student in a mathematics class? How do you manage in the subject?

4. Do you think mathematics is useful or useless?

5. What are your thoughts and feelings about journal writing as a mathematics class activity?

6. Do you find it helpful? If yes, in what way?

The first four questions tackle the students' attitude toward mathematics while last two attempt to explore their perception on journal writing as a mathematics class activity. With the permission of the students, the discussion was audio-recorded for the accurate transcription and coding of data.

For the qualitative data analysis, a transcription grid was developed for each of the six questions. The responses were carefully and objectively coded. Key terms from the preliminary codes were studied and then grouped according to similarity to obtain the emerging themes. Further, frequencies of reply were noted to establish relevant ideas that were raised during the interview.

Triangulation was used to validate the analysis for the qualitative data. Different studies, either those that conform or contradict were gathered and related to the results of this study to establish soundness of the findings conveyed. Also, the results of the quantitative data analysis were linked up with the qualitative data to further strengthen and support the findings.

Throughout the study, ethical considerations were followed and observed. With the respondents being of minor ages, letters of consent were sent to the parents informing them of the nature and purpose of the study. These were also discussed with the students and their consent to participate was also sought before the conduct of any data gathering. Anonymity of the respondents was assured. Any kind of deception or exaggeration about the aims of the study as well as results in the data gathering was certainly avoided.

\section{RESULTS AND DISCUSSION}

\subsection{Students' Attitude toward Mathematics}

SATM [12] measures the attitude in four aspects namely liking or disliking mathematics, tendency to engage in or avoid mathematical activities, a belief that one is good or bad in mathematics, and a belief that mathematics is useful or useless. The succeeding four tables show the results for the pretest and posttest of the respondents.

In terms of liking or disliking mathematics, majority of the students during the pretest were at a range of slightly disliking $(n=15)$ to slightly liking $(n=14)$ the subject as shown in Table 1 . Although more students showed to have a liking in the subject $(n=24)$ compared to those who do not $(n=20)$, still no student resulted to have very much liking in it. For the posttest, there was a slight increase in the number of students who like the subject $(n=3)$. Consequently, majority of the students showed to have a slight liking in mathematics unlike in the pretest where more students somewhat disliked it.

Table 1. Liking or Disliking Mathematics

\begin{tabular}{lcccc}
\hline \multicolumn{1}{c}{ Attitude } & \multicolumn{2}{c}{ Pretest } & \multicolumn{2}{c}{ Posttest } \\
& Frequency & $\%$ & Frequency & $\%$ \\
\hline Very much disliking math & 2 & 4.55 & 1 & 2.27 \\
Disliking math & 3 & 6.82 & 1 & 2.27 \\
Somewhat disliking math & 15 & 34.09 & 15 & 34.09 \\
Somewhat liking math & 14 & 31.82 & 16 & 36.36 \\
Liking math & 10 & 22.73 & 9 & 20.45 \\
Very much liking math & 0 & 0.00 & 2 & 4.55 \\
\hline
\end{tabular}

The Role of Journal Writing in Senior High School Students' Attitude toward Mathematics(Ivee K. Guce) 
For the students' tendency to engage in or avoid mathematical activities, the results are summarized in Table 2. For both the pretest and posttest, the majority have a (low) tendency to engage in the subject rather than avoid it. Further, it is worth-noting that there was a shift from mostly having the tendency to avoid mathematical activities to predominantly having the tendency to engage in them (from $n=25$ to $n=20$ ). Evidently, there was an increase in number, from $19(43 \%)$ to $24(55 \%)$, of those students who showed to have a tendency to engage in mathematical activities during the posttest.

Table 2. Tendency to Engage in or Avoid Mathematical Activities

\begin{tabular}{|c|c|c|c|c|}
\hline \multirow{2}{*}{ Attitude } & \multicolumn{2}{|c|}{ Pretest } & \multicolumn{2}{|c|}{ Posttest } \\
\hline & Frequency & $\%$ & Frequency & $\%$ \\
\hline High tendency to avoid mathematical activities & 2 & 4.55 & 1 & 2.27 \\
\hline Moderate tendency to avoid mathematical activities & 8 & 18.18 & 4 & 9.09 \\
\hline Low tendency to avoid mathematical activities & 15 & 34.09 & 15 & 34.09 \\
\hline Low tendency to engage in mathematical activities & 16 & 36.36 & 18 & 40.91 \\
\hline Moderate tendency to engage in mathematical activities & 3 & 6.82 & 6 & 13.64 \\
\hline High tendency to engage in mathematical activities & 0 & 0.00 & 0 & 0.00 \\
\hline
\end{tabular}

Table 3 shows the results of the students' belief as to whether they are good or bad in mathematics. Majority of the students for both pretest $(n=18)$ and posttest $(n=15)$ slightly believe that they are not performing well in the subject. Although there is an increase in the number of students who believe that they are good in mathematics during the posttest, results revealed that the number of students who see themselves as poor in mathematics are still predominant than those who feel otherwise. As a matter of fact, there were 34 $(77 \%)$ and 27 (61\%) students under this case for pretest and posttest, respectively.

Table 3. Belief that One is Good or Bad in Mathematics

\begin{tabular}{|c|c|c|c|c|}
\hline \multirow{2}{*}{ Attitude } & \multicolumn{2}{|c|}{ Pretest } & \multicolumn{2}{|c|}{ Posttest } \\
\hline & Frequency & $\%$ & Frequency & $\%$ \\
\hline Highly believes that one's self is bad in mathematics & 5 & 11.36 & 6 & 13.64 \\
\hline Moderately believes that one's self is bad in mathematics & 11 & 25.00 & 6 & 13.64 \\
\hline Slightly believes that one's self is bad in mathematics & 18 & 40.91 & 15 & 34.09 \\
\hline Slightly believes that one's self is good in mathematics & 6 & 13.64 & 13 & 29.55 \\
\hline Moderately believes that one's self is good in mathematics & 4 & 9.09 & 3 & 20.55 \\
\hline Highly believes that one's self is good in mathematics & 0 & 0.00 & 1 & 6.82 \\
\hline
\end{tabular}

Among the four aspects of measuring students' attitude toward mathematics, the belief that mathematics is useful or useless stood out to have the best results in terms of having a positive mindset among respondents. For both pretest and posttest, no student strongly believes that mathematics is useless. In fact, majority of the students consider the usefulness of mathematics with $93 \%(n=41)$ for the pretest and $95 \%(\mathrm{n}=42)$ for the posttest. Table 4 shows belief that mathematics is useful or useless.

Table 4. Belief that Mathematics is Useful or Useless

\begin{tabular}{lcccc}
\hline \multicolumn{1}{c}{ Attitude } & \multicolumn{2}{c}{ Pretest } & \multicolumn{2}{c}{ Posttest } \\
& Frequency & $\%$ & Frequency & 0.00 \\
Highly believes that mathematics is useless & 0 & 0 & 0 & 0.00 \\
Moderately believes that mathematics is useless & 1 & 2.27 & 0 & 4.55 \\
Slightly believes that mathematics is useless & 2 & 4.55 & 2 & 40.91 \\
Slightly believes that mathematics is useful & 19 & 43.18 & 18 & 40.91 \\
Moderately believes that mathematics is useful & 16 & 36.36 & 18 & 13.64 \\
Highly believes that mathematics is useful & 6 & 13.64 & 6 & \\
\hline
\end{tabular}

Comparing the mean results of the pretest and posttest for the four subscales using paired sample test, it appears that there is a significant difference in the pre and post-tests for liking or disliking mathematics $(p=0.002, p<0.05)$ and tendency to engage in or avoid mathematical activities $(p=0.009$, $p<0.05)$. Even though there was increase in the means in posttests for the two remaining subscales, no significant difference occurred between the pre and post-tests. Table 5 shows pretest-posttest mean score results 
Table 5. Pretest-Posttest Mean Score Results

\begin{tabular}{lcccccc}
\hline \multicolumn{1}{c}{ Subscale } & Test & $\mathrm{N}$ & $\mathrm{Mean}$ & $\begin{array}{c}\text { Std. } \\
\text { Deviation }\end{array}$ & $\mathrm{t}$-value \\
\hline \multirow{2}{*}{ Liking or disliking mathematics } & Pretest & 44 & 3.5964 & 0.84932 & -3.315 & 0.002 \\
\multirow{2}{*}{$\begin{array}{l}\text { Tendency to engage in or avoid mathematical } \\
\text { activities }\end{array}$} & Posttest & 44 & 3.8205 & 0.86783 & 0.75305 & -2.733 \\
& Posttest & 44 & 3.4966 & 0.75890 & 0.009 \\
Belief that one is good or bad in mathematics & Pretest & 44 & 2.9855 & 0.89511 & -1.966 \\
& Posttest & 44 & 3.1409 & 0.94324 & 0.056 \\
Belief that mathematics is useful or useless & Pretest & 44 & 4.3205 & 0.63730 & -1.007 \\
\end{tabular}

The remaining paragraphs of this section present the responses given by the students in the focus group discussion concerning their attitude towards mathematics as well as the discussion linking the quantitative and qualitative data in the study.

Data showed that all ten respondents expressed liking in the subject but not to the same extent. While three directly acknowledged their liking in the subject, there are seven who mentioned that they are middling in terms of actually enjoying the subject. They do not totally like it yet they do not dislike it. This agrees with the result in the SATM where somewhat liking math got the most number of frequency. When asked if he likes mathematics or not, Student 7 said that "it is okay" for him. He further adds that there certainly are times when he likes the subject but not to a point when it is all that he enjoys. Analyzing the responses of the students, three points emerged as reasons why they enjoy mathematics: its relevance or worth, its being challenging, and those certain topics that they like. The first is the most answered response. From past studies, students feel at ease in solving real-life mathematical problems because for them they can be solved at different levels and in different ways [44]-[45]. When students become aware of the connections and relevance of mathematics in their lives, they tend to see its importance [46].

When it comes to engaging themselves in mathematical activities, six students expressed willingness to engage in such activities while the remaining conveyed apprehensions in doing so. The former likes engaging in mathematical activities for different reasons. For one, Student 3 shared that doing those activities allows him to explore the subject who was seconded by Student 8 who narrated that in solving mathematical problems "he gets to discover how it (math) can be applied to real-life". Also, students believe that by engaging in mathematical activities, their skills in the subject will be developed, as articulated by Student 2. This response was complemented by that of Student 6' who said: "I feel very happy whenever I get results from solving math problems."

The increase in the students' enjoyment in mathematics and their willingness to engage in the subject aligns with the study made by Sanchal and Sharma [47]. Their findings suggest that engagement level also increases with an increased number of students enjoying mathematics lessons while studying the subject. They further stated that seeing the relevance of mathematics lessons, students' attitudes toward the subject also improved.

As regards how the students rate themselves at how they fare in the subject, half of them regard themselves as average students in mathematics. This is in contrast with the quantitative data which revealed that by and large, students felt that they are not good in math. For both pretest and posttest, the biggest component is for the slightly believes that one's self is bad in mathematics, which gave $41 \%$ and $34 \%$, respectively. Student 2 recounted that there are topics which she could understand and there are others which she could not. Student 9 made a follow-up statement on this by saying "There are tests which I was able to pass and there are also some which I failed." When asked about how they manage in the subject, most of these students conveyed that they persevere in the subject by not easily giving up when trying solving mathematical problems. They seek the help of others as well.

For the last subscale - the belief that mathematics is useful or useless, students were one in regarding that mathematics is useful. This is consistent with the results in the pretest and posttest which show that majority of these students believe in the usefulness of mathematics. In the interview, not only did they articulate the relevance of mathematics in terms of its practical applications; they also claimed that mathematics hones them to be better students. Such is evident in the following transcribed responses: "Mathematics trains us to be more persevering in finding solution to any given problem" (Student 3), "Doing numbers is not the only essence of mathematics but also that of being logical thinker" (Student 7), "It teaches us values like determination and independence" Student 1 and "Mathematics is useful because I am trained to be critical thinker" (Student 9). The last was affirmed by Student 10 by saying: "In reality, you

The Role of Journal Writing in Senior High School Students' Attitude toward Mathematics(Ivee K. Guce) 
may not actually apply the exact things that were learned in the classroom. Yet in the future, we will be trained to be critical thinkers."

The results using the quantitative and qualitative data indicates that the students' attitude toward mathematics is generally positive for the subscales: liking or disliking mathematics, tendency to engage in or avoid mathematical activities, and belief that mathematics is useful or useless. Concerning belief that one's self is good or bad in mathematics, the result is slightly negative.

\subsection{Students' Insights on Journal Writing}

In the responses of the students regarding their thoughts and feelings about journal writing as a mathematics class activity, it is very evident that they grasp the activity's benefits to both the teacher and the students. Student 1 was first to mention that he finds journal writing as a good idea because the activity "enables the teacher to know what topics the students find easy or difficult". He adds: "If she (teacher) reads that many are having difficulty at a certain topic, she might discuss it again for us next meeting so we can understand it". Another interesting point was raised by Student 2 saying that "When students give feedback, the teacher is able to think what needs to be addressed and consider interesting ideas that she can use in class." This was agreed upon by Student 7 who shared: "It is a way for the teacher to know what needs further improvement or review." On the other hand, Student 7 and Student 10 expressed on different occasions that journal writing creates time for them to reflect on what has been learned and what yet needs to be learned.

The students' take on the usefulness of the activity tackles two things that journal provides: communication and reflection. Indeed, journal writing served as an indirect communication between them and the teacher. Student 3 told that she likes the activity because through it "gives the students a chance to let the teacher know their concerns". Likewise, Student 9 recounted that "Journal writing is a good idea for the students who feel shy to tell the teacher what they do not understand." to which Student 6 agreed on. According to him many feel shy to actually tell the teacher when they do not grasp certain topics during class.

Of the ten respondents, Student 10 had the most profound thing to say about the activity in that it encapsulates the points shared by the rest. He said:

"It is good to have journal writing because it is beneficial primarily for Miss (the teacher)

and then for us. Through the activity, she can assess if there are still some things that

we don't understand. And for us, it gives us time to reflect on what we have learned, what

part of the lesson we find difficult, and what areas we need to improve on."

All in all, three themes emerged concerning the students' insights about journal writing. First, journal writing was perceived by the students as a useful communication between them and the teacher. Writing actually offers an alternative to the usual classroom communication which is mostly oral in nature [48]. According to Liebars [27], the activity provides a means of communication between the teacher and students, and affords the opportunity for the students to communicate mathematical ideas with their teacher. Further, journal writing gives the students the chance to realize when to ask for help which eventually contributes to the teaching-learning environment [49].

Since for the students, an open line of communication was created through journal writing, they recognized as well that the activity enables their teacher to assess their learning. It helps the teacher strategize in her instruction. In the study made by Addison [24], one of the rewards of students' journal writing is increased awareness of student comprehension of concepts, feelings, and attitude toward mathematics. What the students share about their learning experiences allows the teacher to monitor the students' understanding of the topic [50] and affect how teachers approach the subject matter again [51].

Recognizing that the activity not only benefits the teacher but also the students are the third theme deduced from the responses. This conforms to the findings made by Van Der Molen [15] and Odafe [49]. The former emphasized that incorporating reflective journaling is beneficial for both instructor and the students. According to him, the benefits of communication and improving student learning experience outweigh the problem of reflective journaling as time consuming. While, for Odafe [49], he found that when teacher and students become partners in mathematics teaching and learning process, reflection process results in improved student learning environment.

Linking journal writing with students' attitude toward mathematics draws in an indirect association between the two. In this study, journals were used by the teacher to identify the problems that the students may have and then to eventually improve their attitude toward mathematics. The statements given by the students about journal writing and the information about their attitude toward mathematics for both pretest and posttest coincide in the idea that journal writing is an aid for a teacher to improve students' attitude toward mathematics. In particular, the measure or students' liking mathematics and tendency to engage in the subject changed positively during the period when journal writing was implemented. This is supported by a

IJERE Vol. 7, No. 2, June 2018: $132-141$ 
number of studies. Firstly, Addison [24] found that "journals offer a glimpse into what the students liked and disliked about mathematics classes" (p. 34). In connection with student engagement, Klein, Pflederer \& Truckenmiller [52], obtained a similar result to this study's. His findings showed that journals reflected greater enjoyment of the class which ultimately increased the motivational level of everyone involved. Teachers can find ways to encourage student engagement in mathematics [46] which can be achieved by implementing meaningful activities for them [53]. The teacher's methods have a major influence on students' attitude toward mathematics [13], [54].

\section{CONCLUSION}

In math classroom where the primary focus is computation and not the motivating factors that will maximize learning, students are often left being disinterested in mathematics. Teachers have the primary role of creating opportunities to connect with the students to establish matters that work against positive attitude toward the subject. This study explored how journal writing takes part in changing students' attitude toward mathematics. As hypothesized, the implementation of the said activity improved the attitude of the students toward the mathematics mainly in two areas-liking the subject and willingness to engage in mathematical activities. The students perceive journal writing as a helpful tool for them to enjoy mathematics and engage in it. The activity, thus, may be regarded as a means to improve one's attitude in mathematics. The benefits of writing in a mathematics class cannot be dismissed for the writings shall bind closer the teacher and the students in attaining an effective learning environment. What the students share will direct the teacher in improving the attitude of the students toward the subject.

\section{REFERENCES}

[1] Carpenter, T., Corbitt, M., Kepner, H., Lindquist, M., \& Reys, R. (1980). Students' affective responses to mathematics: Results and implications from national assessment. Arithmetic Teacher, 27(4), 34-37.

[2] Paulos, J. (1988). Innumeracy. New York: Hill and Wang.

[3] Shutt, J. (2003). The use of writing as foundation for classroom environment promoting engagement in the middle level mathematics classroom: A lesson from the field (Master's thesis). Retrieved from ProQuest Dissertations and Theses database. (UMI no. 1416404)

[4] Block, N. (2005). How reading and writing influence student engagement and learning in the math classroom (Masters Thesis). Retrieved from ProQuest Dissertations and Theses database. (UMI no. 1430033)

[5] Loud, B. (1999). Effects of journal writing on attitudes, beliefs, and achievement of students in a college mathematics course (Dissertation). Retrieved from ProQuest Dissertations and Theses database. (UMI no. 9923962)

[6] Jurdak, M. \& Zein, R. A. (1998). The effect of journal writing on achievement in and attitudes toward mathematics. School Science and Mathematics, 98(8), 412-419.

[7] Millican, B. R. (1994). The effects of writing-to-learn tasks on achievement and attitude in mathematics (Doctoral Dissertation, University of North Texas, 1994) Dissertation Abstracts International, 55(4), 897A.

[8] Thurlow, D. (1995). The effects of journal writing on fifth grade subjects' mathematics attitudes and achievement. Unpublished doctoral dissertation, University of Memphis.

[9] Sample, C. (1998). Urban Algebra I students' perceptions of journal writing and its effects on achievement with integers and students' attitudes toward mathematics (Dissertation). Retrieved from ProQuest Dissertations and Theses database. (UMI no. 9842390)

[10] Moenikia, M. \& Zahed-Babelan, A. (2010). A study of simple and multiple relations between mathematics attitude, academic motivation and intelligence quotient with mathematics achievement. Procedia Social and Behavioral Sciences, 2, 1537-1532.

[11] Hodges, C. \& Kim, C. (2013). Improving college students' attitudes toward mathematics. TechTrends, 57(4). 59-66

[12] Guce, I. \& Talens, J. (2013). Scale on attitude toward mathematics (SATM). Educational Measurement and Evaluation Review, 4. 100-107.

[13] Akinsola, M. K. \& Olowojaiye, F. B. (2008). Teacher instructional methods and student attitude towards mathematics. International Electronic Journal of Mathematics Education, 3, 61-73.

[14] Ma, X. \& Kishor, N. (1997). Assessing the relationship between attitude toward mathematics and achievement in mathematics: a meta - analysis. Journal for Ma, X. \& Kishor, N. (1997). Assessing the relationship between attitude toward mathematics and achievement in mathematics: a meta - analysis. Journal forResearch in Mathematics Education, 28(1), 26 - 47.Research in Mathematics Education, 28(1), 26 - 47.

[15] Van Der Molen, L. (2015). Action research: Reflective journaling within middle grades

[16] Latulippe, C., \& Latulippe, J. (2013). Student perceptions of writing projects in a university differential-equations course. International Journal of Mathematical Education in Science and Technology, 45(1), 1-11.

[17] Borasi, R., \& Rose, B. (1989). Journal writing and mathematics instruction. Educational Studies in mathematics, 20(4), 347-365.

[18] LeGere, A. (1991). Collaboration and writing in the mathematics classroom. Mathematics Teacher. 84(3). 166-171.

[19] Nahrgang, C. L., \& Petersen, B. T. (1986). Using writing to learn mathematics. Mathematics teacher, 79(6), (September 1986), $461-465$.

The Role of Journal Writing in Senior High School Students' Attitude toward Mathematics(Ivee K. Guce) 
[20] Miller, D. J., \& England, D. A. (1989). Writing to learn algebra. School Science and Mathematics, 89(4), 299-312.

[21] Ford, M. (1990). The writing process: A strategy for problem solvers. Arithmetic Teacher. 38(3). 35-38.

[22] Stewart, C., \& Chance, L. (1995). Making connections: Journal writing and the Professional Teaching Standards. Mathematics Teacher, 88(2), 92-95.

[23] Guce, I. (2017). Investigating college students' views on mathematics learning through reflective journal writing. International Journal of Evaluation and Research in Education, 6(1). 38-44.

[24] Addison, L. (1972). A teacher's reflection on the implementation of journal writing in mathematics. University of Alberta, Lethbridge, Alberta.

[25] Countryman, J. (1992). Writing to learn mathematics. Portsmouth, NH: Heinemann.

[26] Linn, Mary M. (1987). Effects of journal writing on thinking skills of high school geometry students. Unpublished master's thesis, University of North Florida, Jacksonville, FL.

[27] Liebars, C. (1997). Journal writing: A model for mathematics teacher education. Retrieved from ERIC database. (ED446933)

[28] Miller, D. (1993). Making the connection with language. Arithmetic Teacher. 40(61), 311-316.

[29] Burton, G. (1985). Writing as a way of knowing in a mathematics education Class. Arithmetic Teacher. 33(4). 4045.

[30] Baker, B. (1994). Analysis of the effect of in-class writing on the learning of function concepts in college algebra (Dissertation). Retrieved from ProQuest Dissertations and Theses database. (UMI no. 9503527)

[31] Hiemstra, R. (2001). Uses and benefits of journal writing. New Directions for Adult and Continuing Education, 90, 19-26.

[32] Lew, M. D. N., \& Schmidt, H. G. (2011). Self-reflection and academic performance: Is there a relationship? Advances in Health Sciences Education, 16(4), 529-545.

[33] Youngju, L. (2010). Blended teacher supports for promoting open-ended questioning in pre-k science activities (Dissertation). Retrieved from ProQuest Dissertations and Theses database. (UMI no. 3437731)

[34] McLeod, S. A. (2014). Lev Vygotsky. Retrieved from www.simplypsychology.org/vygotsky.html

[35] Vygotsky, L. S. (1978). Mind in society: The development of higher psychological processes. Cambridge, MA: Harvard University Press.

[36] Schön, D. (1983). The Reflective Practitioner: How professionals think in action. London: Temple Smith

[37] Reflection models and frameworks. (n.d.). Retrieved from fttp://www.bradford.ac.uk/wimba-files/skillspace/Reflective_Writing_HTML/page_04.html

[38] Munby, H. (2012). Reflection in action and reflection on action. Retrieved from http://docs.lib.purdue.edu/cgi/viewcontent.cgi?article=1390\&context=eandc

[39] Dougherty, B., \& Matsumoto, A. (1995). Revitalizing first-year algebra through Problem solving with HALP. Mathematics Teacher. 88(4). 708-714.

[40] Gay, L. R, \& Airasian, P. (2003). Educational research: Competencies for analysis and applications (7th ed.). Upper Saddle River, NJ: Merrill.

[41] Heyvaert, M., Maes, B., \& Onghena, P. (2011). Mixed methods research synthesis: definition, framework, and potential. Qual Quant, 47, 659-676. DOI 10.1007/s11135-011-9538-6

[42] Creswell, J. W., \& Tashakkori, A. (2007). Developing publishable mixed methods manuscripts. Journal of Mixed Methods Research, 1, 107-111.

[43] Creswell, J. W., \& Plano Clark, V. L. (2011). Designing and conducting mixed methods research (2nd ed.). Thousand Oaks, CA: Sage Publications, Inc.

[44] Van Den Heuvel-Panhuizen, M. (2005). The role of contents in assessment problems in mathematics. For the Learning of Mathematics, 25(2), 2-23.

[45] Widjaja, W. (2013). The use of contextual problems to support mathematical learning. Indonesian Mathematical Society Journal on Mathematics Education, 4(2), 151-159.

[46] Sullivan, P., \& McDonough, A. (2007). Eliciting positive student motivation for learning mathematics. In J. Watson \& K. Beswick (Eds.), Proceedings of the 30th annual conference of the mathematics education research group of Australasia (pp. 698-707). Australia: MERGA.

[47] Sanchal A. \& Sharma, S. (2017). Students attitudes towards learning mathematics: Impact of teaching in a sporting context. Teachers and Curriculum, 17(1), 89-99.

[48] Baxter, J. A., Woodward, J., \& Olson, D. (2005). Writing in mathematics: An alternative form of communication for academically low-achieving students. Learning Disabilities Research and Practice, 20(2), 119-135.

[49] Odafe, V.U. (2007). Teaching and Learning Mathematics: Student Reflection Adds a New Dimension. In D.K. Pugalee, A. Rogerson, and A. Schinck (Eds.) Proceedings of the Ninth International Conference: Mathematics Education in a Global Community (pp. 486-490) ISBN 83-919465-8-4

[50] Amir, Y. B., \& Lianghuo, F. (2000). Exploring how to implement journal writing effectively in primary mathematics in Singapore. Retrieved from ERIC database. (ED482958)

[51] Mannion, G. (2001). Journal writing and learning: Reading between the structural, holistic, and post-structural lines. Studies in Continuing Education, 23(1), 95-115.

[52] Klein, C., Pflederer, B., \& Truckenmiller, M. (1998). Increasing student motivation through cooperative learning, writing in mathematics, and multiple intelligences. Retrieved from ERIC database. (ED436351)

[53] Kacerja, S. (2012). Real-life contexts in mathematics and students' interests: An Albanian study (Doctoral dissertation, University of Agder, Kristiansand, Norway). Retrieved from http://www.nb.no/idtjeneste/URN:NBN:no-bibsys_brage_37094 
[54] Mensah, J. K., Okyere, M., \& Kuranchie, A. (2013). Student attitude towards mathematics and performance: Does the teacher attitude matter? Journal of Education and Practice, 4(3), 132- 139.

\section{BIOGRAPHY OF AUTHOR}

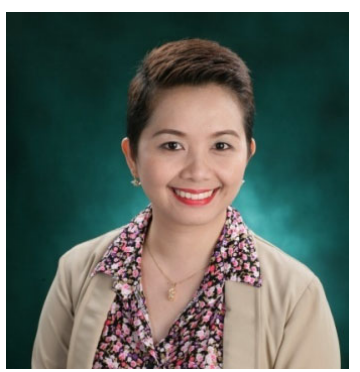

Dr. Ivee K. Guce is a mathematics teacher and a researcher. She is an associate professor of the Mathematics Department of the College of Education, Arts and Sciences of the De La Salle Lipa. She finished her BS Mathematics Major in Actuarial Science at the University of Sto. Tomas. She obtained her Master in Mathematics degree from the De La Salle University, and earned the degree Philosophy in Education Major in Mathematics from the University of Batangas.

Dr. Guce is currently the Program Chair in Mathematics. Besides teaching, she is actively engaged in research. She has published a number of papers at international journals and presented her works at several conferences both locally and internationally. Most of her works are focused on mathematics education. Her passion for teaching mathematics is her motivation in sharing her knowledge to other educators through the studies she conducts 